\title{
An Entzia-dominated marsh-type agglutinated foraminiferal assemblage from a salt marsh in Tubli Bay, Bahrain
}

\author{
Michael A. Kaminski ${ }^{1}$, Abduljamiu O. Amao' ${ }^{2}$ Thomas F. Garrison ${ }^{3}$, \\ Flavia Fiorini ${ }^{4}$, Simeon Magliveras ${ }^{5}$, Bassam S. Tawabini ${ }^{6}$, Anna Waśkowska \\ ${ }^{1}$ King Fahd University of Petroleum \& Minerals, Geosciences Department; Dhahran 31261, Saudi Arabia; \\ e-mail: kaminski@kfupm.edu.sa (corresponding author); ORCID ID: 0000-0002-7344-5874 \\ ${ }^{2}$ King Fahd University of Petroleum \& Minerals, Center for Integrated Petroleum Research; Dhahran 31261, Saudi Arabia; \\ e-mail:amao@kfupm.edu.sa; ORCID ID: 0000-0001-8203-851X \\ ${ }^{3}$ King Fahd University of Petroleum \& Minerals, Chemistry Department; Dhahran 31261, Saudi Arabia; \\ e-mail: thomasg@kfupm.edu.sa; ORCID ID: 0000-0001-6458-5819 \\ ${ }^{4}$ Micropress Europe; al. A. Mickiewicza 30, 30-059 Krakow, Poland; \\ e-mail: flaviafiorini73@gmail.com; ORCID ID: 0000-0003-4317-3553 \\ ${ }^{5}$ King Fahd University of Petroleum \& Minerals, Department of Global \& Social Studies; Dhahran 31261, Saudi Arabia; \\ e-mail: simeon@kfupm.edu.sa; ORCID ID:0000-0002-7112-2887 \\ ${ }^{6}$ King Fahd University of Petroleum \& Minerals, Geosciences Department; Dhahran 31261, Saudi Arabia; \\ e-mail: tawabini@kfupm.edu.sa; ORCID ID: 0000-0002-0096-2723 \\ ${ }^{7}$ AGH University of Science and Technology, Faculty of Geology, Geophysics and Environmental Protection; \\ al. A. Mickiewicza 30, 30-059 Krakow, Poland; e-mail: waskowsk@agh.edu.pl; ORCID ID: 0000-0003-4090-8534
}

(C) 2020 Authors. This is an open access publication, which can be used, distributed and reproduced in any medium according to the Creative Commons CC-BY 4.0 License requiring that the original work has been properly cited.

Received: 11 July 2020; accepted: 29 August 2020; first published online: 19 October 2020

\begin{abstract}
A salt-marsh assemblage of agglutinated foraminifera was recovered from a salt marsh on the east side of Tubli Bay in eastern Bahrain. This locality is one of the last remaining patches of salt marsh on the east coast of Tubli Bay. The salt marsh is covered by a single marsh plant species, Arthrocnemum macrostachyum. Samples were collected from beneath the Arthrocnemum canopy in two transects beginning at the maximum landward extent of halophytic plants in the high marsh and extending to a tidal channel at the seaward side of the low marsh. A distinct elevation-related zonation in foraminifera is observed from the high marsh to the low marsh. The trochamminids Entzia macrescens and Trochammina inflata are characteristic of the high marsh, whereas Ammonia, Elphidium, Peneroplis and smaller miliolids become common in the middle part of the marsh transect. The tidal channel at the lower limit of the marsh contains an assemblage dominated by Ammonia, Elphidium, adult specimens of Peneroplis, and smaller miliolids, with Clavulina and Agglutinella as the only agglutinated taxa. Living specimens of Entzia and Trochammina were observed during the winter 2019-2020 sampling season, whereas samples collected in Autumn 2019 contained only dead specimens. One new species, ?Sigmoilina canisdementis sp. nov., is described herein. This is the first report of a live Entzia-dominated salt marsh assemblage in the Arabian Gulf region.
\end{abstract}

Keywords: Arabian Gulf, Bahrain, Salt Marsh, agglutinated foraminifera

\section{INTRODUCTION}

For more than half a century, salt-marsh foraminifera have been widely accepted as useful bioindicators for past sea level change and reconstructing the Holocene. Beginning with the work of Bartenstein \& Brand (1938), Cushman \& Brönnimann (1948), Andersen (1951), Saunders (1957) 
and Pfleger (1960, 1970), it became apparent that salt marshes contain unique assemblages of agglutinated foraminifera consisting mainly of a diverse range of trochamminids. Because saltmarsh foraminifera (and their presumed carriers, the migratory shore birds) have wide geographical distribution and distinct vertical ranges, the use of agglutinated foraminifera as bioindicators has increasing importance in different parts of the world in understanding the rate of relative sea level change especially with the current scenario of global warming and predicted global sea level rise.

The pioneering studies of Scott \& Medioli (1978, 1980) have shown that the spatial distribution of agglutinated foraminifera in temperate salt marshes may be closely related to the tide level. For example, a salt-marsh foraminiferal species, Entzia macrescens (Brady), was recorded by Scott \& Medioli (1980) just below the level of higher high water (HHW), above which the living foraminifera rapidly disappear. Other marsh foraminifera (i.e., Tiphotrocha, Trochammina, Miliammina, and calcareous benthic species) occur at lower elevations with respect to HHW, and consequently the occurrence of such foraminifera in sediment cores can be used as indicators of past sea-level changes (see Horton \& Edwards 2006). Later studies by Scott et al. (1990) have shown that E. macrescens are widely distributed along the Atlantic coastline of North and South America. Furthermore, E. macrescens has been found across the globe in the salt marshes of NW Europe (Bartenstein \& Brand 1938), North America (Scott \& Medioli 1980), the Caspian Sea (Shmal'gauzen 1950) and the Bay of Bengal (Kumar et al. 2014). Two distinct phylotypes of $E$. macrescens have already been reported in Europe (Holzmann \& Pawlowski 2017), and considering the large distances between populations of Entzia from Europe, North and South America and the Indian coast one can expect to find additional cryptic species (M. Holzmann 2020, personal communication). The species has even colonized saline springs found near the salt mines of central Transylvania (Daday 1884, Filipescu \& Kaminski 2011). The E. macrescens population in Transylvania is genetically identical to the population from South Wales, and specimens have likely been transported by birds during seasonal migrations (Holzmann \& Pawlowski 2017).
Along the shores of the western Arabian Gulf, the last remaining salt marshes are currently under threat from coastal development and land reclamation. In this study, we are reporting a survey of foraminifera found in one of the extant salt marshes that has not been developed. Although studies of benthic foraminifera have been conducted from the intertidal zone in Bahrain (Basson \& Murray 1995, Amao et al. 2016, Garrison 2019), until now, there have been no reported surveys of salt-marsh foraminifera found in vegetated marshes.

\section{STUDY AREA}

The study site was a $100 \mathrm{~m}$ by $300 \mathrm{~m}$ patch of vegetated salt marsh and mangal located adjacent to an automotive dealership on the Shaikh Jaber Al-Subah Highway in Sitra, Bahrain. The site is located on the eastern side of Tubli Bay (Fig. 1). Tubli Bay is a shallow wedge-shaped inlet (average depth $5 \mathrm{~m}$ ) with a surface area of $10 \mathrm{~km}^{2}$ located in northeastern Bahrain (Seedo et al. 2017). It is home to large numbers of pink flamingos, egrets, and other wading birds, but its intertidal zone has now been largely reclaimed, particularly on the eastern side in Sitra. The patch of salt marsh and mangroves next to the automotive dealership is the only remaining undisturbed marsh habitat on the eastern side of the bay. The intertidal zone at the studied site (from HHW to the bay) consists of six habitats: (1) a vegetated high marsh covered by a monospecific canopy of the perennial halophyte Arthrocnemum macrostachyum (Mericand), (2) a tidal creek leading to a tidal pool, (3) the highest occurrence of sparse grey mangrove bushes (Avicenna marina), grading into (4) a thick canopy of mature mangrove trees, and on the seaward side, (5) an intertidal mud flat with patches of algal mat cut by tidal channels extending to the low tide mark, and finally (6) the open waters of Tubli Bay (Fig. 1).

This study focuses on the foraminiferal assemblages found within the A. macrostachyum salt marsh, along an elevational transect extending from the highest occurrence of the A. macrostachyum canopy on the landward side to the tidal channel separating the salt marsh from the mangroves on the seaward side (Fig. 2). 


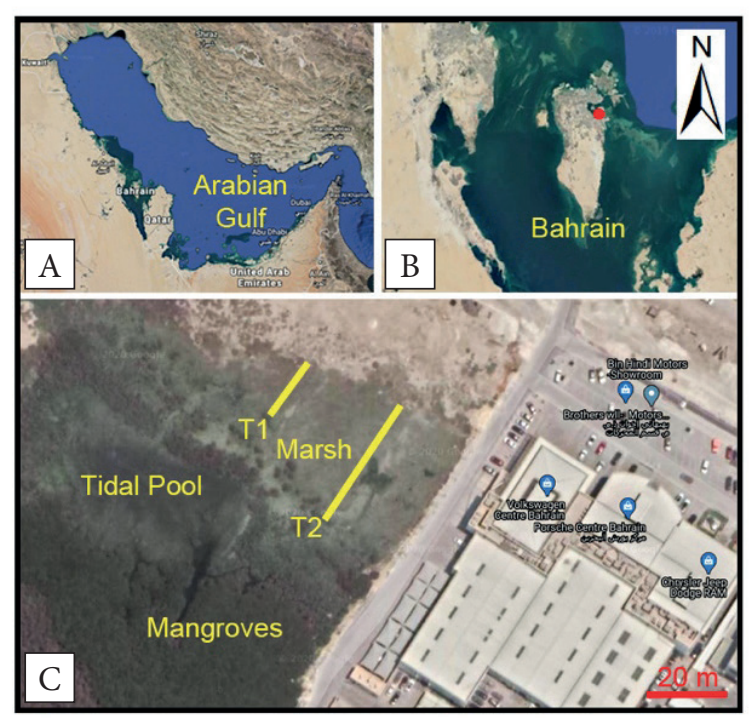

Fig. 1. Location of sample area, all images from Google Maps (A); red dot indicates the sample site in Sitra, Bahrain (B); location of the sampled transects in the salt marsh (C)
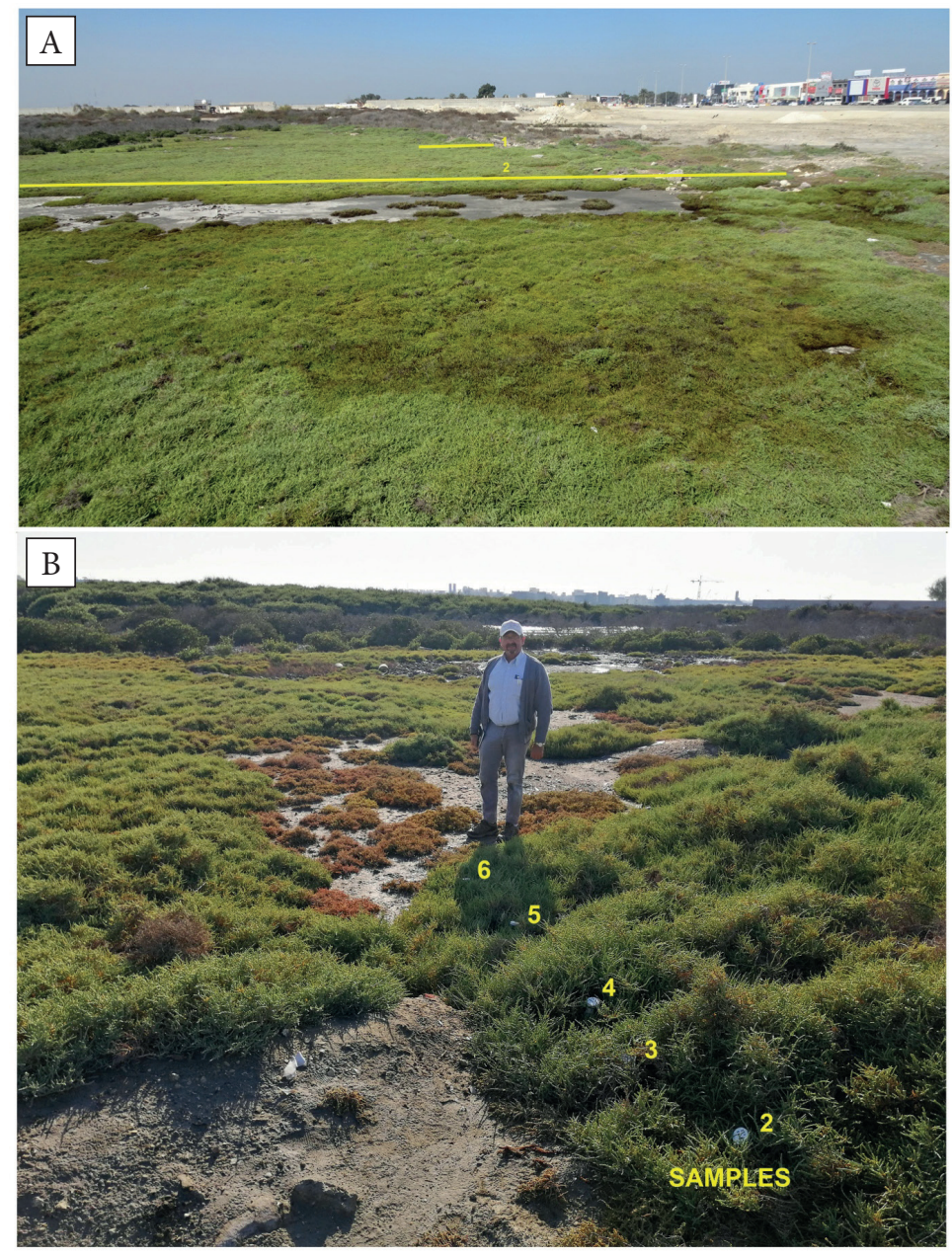

Fig. 2. View of the salt marsh looking northwest from the automobile dealership on the Shaikh Jaber Al-Subah Highway. The sampled transects are indicated with yellow lines (A); close-up view of transect 2, looking west from the landward edge of the salt marsh (B). Photo by Adam Fheed (AGH) 
At the landward edge of the salt marsh, some additional halophytic plants were noted, including Halocnemem strobilaceum (Pallas), Tetraena qatarensis (Hadid), and Cistanche tubulosa (Schenk). Above HHW the upland is sparsely covered by tufts of grass until it meets the highway.

\section{MATERIAL AND METHODS}

Samples were collected from beneath the Arthrocnemum canopy in two transects beginning at the tidal channel at the seaward side of the low marsh and extending to the maximum extent of halophytic plants in the high marsh. The marsh was first sampled for taxonomic purposes on December 7, 2019 (samples VW0-VW5) along the line of transect 1 . Transect 1 was sampled again at the end of January, 2020, and transect 2 was sampled two weeks later on February 13, 2020. On the day transect 2 was collected, air and sediment temperatures were $17^{\circ} \mathrm{C}$. Samples were collected by inserting the mouth of a $125 \mathrm{ml}$ glass sample jar into the sediment underneath an Arthrocnemum plant to a depth of $1 \mathrm{~cm}$, thereby collecting a plug of surficial sediment $4 \mathrm{~cm}$ in diameter and $1 \mathrm{~cm}$ thick. Samples were brought back to the lab within a few hours and soaked in a rose Bengal solution (80\% ethanol with $5 \mathrm{~g}$ rose Bengal powder per litre), for a minimum of two weeks. Samples were gently washed over a $63 \mathrm{~mm}$ sieve, dried in an oven at $60^{\circ} \mathrm{C}$, and split into manageable fractions using a brass microsplitter (Micropress Europe, Poland). Each split sample yielded approximately 300 specimens (typically $1 / 16$ of the original sample), which were drysieved over a $125 \mathrm{~mm}$ sieve, and the foraminifera (both stained and unstained) were picked from the $\geq 125 \mathrm{~mm}$ fraction into cardboard microscope slides. Selected specimens were photographed using a FEI QUANTA 200 FEG SEM at the Laboratory of Critical Elements, Faculty of Geology, Geophysics and Environmental Protection, AGH University of Science \& Technology, Kraków, Poland. The foraminiferal reference slides will be deposited in the collections of the European Micropaleontological Reference Centre in Kraków, Poland.

\section{RESULTS}

Benthic Foraminifera were recovered from all samples in both transects. The sampled transects begin beneath the highest Arthrocnemum plant at the landward edge of the marsh. The total assemblage is tabulated in Tables 1 and 2, with stained and unstained specimens counted separately. In all samples the proportion of stained specimens is small, less than $5 \%$ of the total assemblage.

Table 1

Counts of live/dead specimens in transect 1

\begin{tabular}{|l|c|c|c|c|c|}
\hline \multicolumn{7}{|c|}{ Genus } & $\mathbf{s 0}$ & $\mathbf{s 1}$ & $\mathbf{s 2}$ & $\mathbf{s 3}$ & $\mathbf{s 4}$ \\
\hline Entzia & $0 / 0$ & $3 / 11$ & $0 / 7$ & $0 / 29$ & $3 / 38$ \\
\hline Trochammina & $0 / 0$ & $7 / 57$ & $1 / 10$ & $5 / 29$ & $5 / 89$ \\
\hline Ammonia & $0 / 41$ & $0 / 49$ & $0 / 22$ & $2 / 40$ & $0 / 30$ \\
\hline Elphidium & $0 / 12$ & $0 / 19$ & $0 / 10$ & $0 / 17$ & $0 / 6$ \\
\hline Peneroplis & $0 / 21$ & $0 / 30$ & $0 / 14$ & $0 / 29$ & $0 / 10$ \\
\hline Coscinospira & $0 / 0$ & $0 / 6$ & $0 / 0$ & $0 / 2$ & $0 / 2$ \\
\hline S. canisdementis & $0 / 0$ & $11 / 13$ & $10 / 10$ & $9 / 8$ & $2 / 3$ \\
\hline Clavulina & $0 / 0$ & $0 / 0$ & $0 / 0$ & $0 / 0$ & $0 / 0$ \\
\hline Quinqueloculina & $0 / 30$ & $0 / 59$ & $0 / 57$ & $0 / 98$ & $1 / 42$ \\
\hline Trichohyalus & $0 / 0$ & $1 / 4$ & $0 / 4$ & $3 / 8$ & $0 / 19$ \\
\hline Haynesina/Porosononion & $0 / 0$ & $0 / 0$ & $0 / 1$ & $0 / 4$ & $0 / 0$ \\
\hline Spiroloculina & $0 / 0$ & $0 / 1$ & $0 / 0$ & $0 / 1$ & $0 / 1$ \\
\hline Agglutinella & $0 / 0$ & $0 / 0$ & $0 / 0$ & $0 / 0$ & $0 / 0$ \\
\hline Other & $0 / 0$ & $0 / 1$ & $0 / 0$ & $0 / 0$ & $0 / 0$ \\
\hline
\end{tabular}


Table 2

Counts of live/dead specimens in transect 2

\begin{tabular}{|l|c|c|c|c|c|c|c|c|c|c|c|}
\hline \multicolumn{10}{|c|}{ Transect $\mathbf{1}$} \\
\hline \multicolumn{1}{|c|}{ Genus } & $\mathbf{s 0}$ & $\mathbf{s 1}$ & $\mathbf{s 2}$ & $\mathbf{s 3}$ & $\mathbf{s 4}$ & $\mathbf{s 5}$ & $\mathbf{s 6}$ & $\mathbf{s 7}$ & $\mathbf{s 8}$ & $\mathbf{s 9}$ & $\mathbf{s 1 0}$ \\
\hline Entzia & $1 / 0$ & $0 / 150$ & $1 / 0$ & $1 / 37$ & $1 / 104$ & $2 / 84$ & $1 / 8$ & $5 / 65$ & $7 / 80$ & $0 / 1$ & $0 / 0$ \\
\hline Trochammina & $0 / 0$ & $0 / 82$ & $2 / 5$ & $2 / 48$ & $4 / 64$ & $1 / 47$ & $4 / 12$ & $1 / 90$ & $1 / 52$ & $2 / 7$ & $0 / 2$ \\
\hline Ammonia & $0 / 30$ & $0 / 21$ & $0 / 49$ & $2 / 43$ & $0 / 70$ & $2 / 34$ & $3 / 86$ & $1 / 49$ & $2 / 127$ & $2 / 80$ & $2 / 102$ \\
\hline Elphidium & $0 / 7$ & $0 / 8$ & $0 / 15$ & $0 / 11$ & $0 / 44$ & $0 / 9$ & $0 / 30$ & $0 / 6$ & $0 / 30$ & $2 / 28$ & $1 / 46$ \\
\hline Peneroplis & $0 / 12$ & $0 / 3$ & $0 / 35$ & $0 / 15$ & $0 / 36$ & $0 / 29$ & $0 / 28$ & $0 / 6$ & $0 / 25$ & $0 / 55$ & $5 / 62$ \\
\hline Coscinospira & $0 / 1$ & $0 / 2$ & $0 / 7$ & $0 / 2$ & $0 / 12$ & $0 / 9$ & $0 / 4$ & $0 / 2$ & $0 / 3$ & $0 / 9$ & $0 / 10$ \\
\hline S. canisdementis & $1 / 0$ & $5 / 16$ & $0 / 1$ & $3 / 4$ & $1 / 11$ & $0 / 4$ & $0 / 0$ & $0 / 2$ & $0 / 0$ & $0 / 1$ & $0 / 0$ \\
\hline Clavulina & $0 / 1$ & $0 / 0$ & $0 / 4$ & $0 / 0$ & $0 / 0$ & $0 / 0$ & $0 / 2$ & $0 / 0$ & $0 / 0$ & $0 / 3$ & $0 / 4$ \\
\hline Quinqueloculina & $0 / 39$ & $0 / 38$ & $3 / 99$ & $0 / 84$ & $0 / 99$ & $0 / 85$ & $7 / 93$ & $0 / 38$ & $0 / 62$ & $6 / 120$ & $0 / 142$ \\
\hline Trichohyalus & $0 / 0$ & $1 / 7$ & $0 / 2$ & $0 / 1$ & $2 / 1$ & $0 / 2$ & $1 / 2$ & $1 / 10$ & $0 / 1$ & $0 / 2$ & $0 / 0$ \\
\hline Haynesina/Porosononion & $0 / 4$ & $0 / 0$ & $0 / 0$ & $0 / 0$ & $0 / 3$ & $0 / 1$ & $0 / 1$ & $0 / 1$ & $0 / 2$ & $0 / 0$ & $0 / 1$ \\
\hline Spiroloculina & $0 / 0$ & $0 / 0$ & $0 / 0$ & $0 / 1$ & $0 / 2$ & $0 / 0$ & $0 / 0$ & $0 / 1$ & $0 / 2$ & $0 / 0$ & $0 / 1$ \\
\hline Agglutinella & $0 / 0$ & $0 / 0$ & $0 / 0$ & $0 / 0$ & $0 / 0$ & $0 / 0$ & $0 / 1$ & $0 / 0$ & $0 / 1$ & $0 / 0$ & $0 / 1$ \\
\hline Other & $0 / 0$ & $1 / 0$ & $0 / 0$ & $0 / 0$ & $0 / 1$ & $0 / 2$ & $0 / 1$ & $0 / 1$ & $0 / 0$ & $0 / 2$ & $0 / 0$ \\
\hline
\end{tabular}

A distinct elevation-related zonation in both rose-Bengal stained and unstained benthic foraminifera is observed from the high marsh to the low marsh. The results are discussed separately.

\section{Live assemblage}

Samples collected on December 7, 2019 did not yield any living (rose Bengal stained) foraminifera Living specimens of benthic foraminifera were recovered during the winter 2019-2020 (JanuaryFebruary, 2020) sampling season. The highest occurrence of living foraminifera is found at the landward edge of the Arthrocnemum canopy at HHW. The highest samples are dominated by Entzia macrescens, a slender fusiform smaller miliolid, here named Sigmoilina canisdementis sp. nov. and an occasional specimen of Reophax sp. At higher elevations on the landward side of the marsh Entzia macrescens is dominant, whereas in the middle part of the marsh Trochammina inflata becomes dominant, while Ammonia tepida, Trichohyalus, Elphidium, and miliolids increase in abundance in the seaward direction. The sample from edge of the tidal channel at the lower limit of the marsh (T2, sample 10) contains an assemblage of calcareous benthic foraminifera dominated by the rotaliids Ammonia, Elphidium, and the miliolid Peneroplis.

\section{Dead assemblage}

The dead assemblage is more diverse compared with the live assemblage and is enriched in various miliolid species, including the larger miliolid genera Peneroplis and Coscinospira. At the landward edge of the marsh the trochamminids dominate the dead assemblage (Figs. 3, 4). The trochamminds are generally well-preserved, and therefore the recovered specimens must have been alive recently. Their relative abundances mirror that of the live assemblage. At the landward end of the transects, Entzia is the dominant genus, then Trochammina becomes dominant in the mid- to lower marsh. The larger specimens of Trochammi$n a$ at the studied locality sometimes display deformities of the chambers (Plate 1). The proportion of calcareous benthic foraminifera (rotaliids and miliolids) increases in the seaward direction (Figs. 3, 4). In the high marsh, only juvenile specimens of Peneroplis are observed, while in the middle and low marsh adult specimens were found in association with juvenile specimens of Coscinospira. In the mid- to low marsh calcareous forms dominate the dead assemblages, mostly Ammonia, Elphidium, a diverse assemblage of smaller miliolids (mostly Quinqueloculina with rare specimens of Agglutinella, Articulina, Hauerina, Spiroloculina, Sigmoilina, and Triloculina), and 
rare specimens of Clavulina, Haynesina, Sorites, and Trichohyalus. Large specimens of Peneroplis are particularly common in sample T2-10 (the edge of the tidal channel at the lower end of the marsh). The genus Sorites is found only in the proximity of the tidal channel in the low marsh.

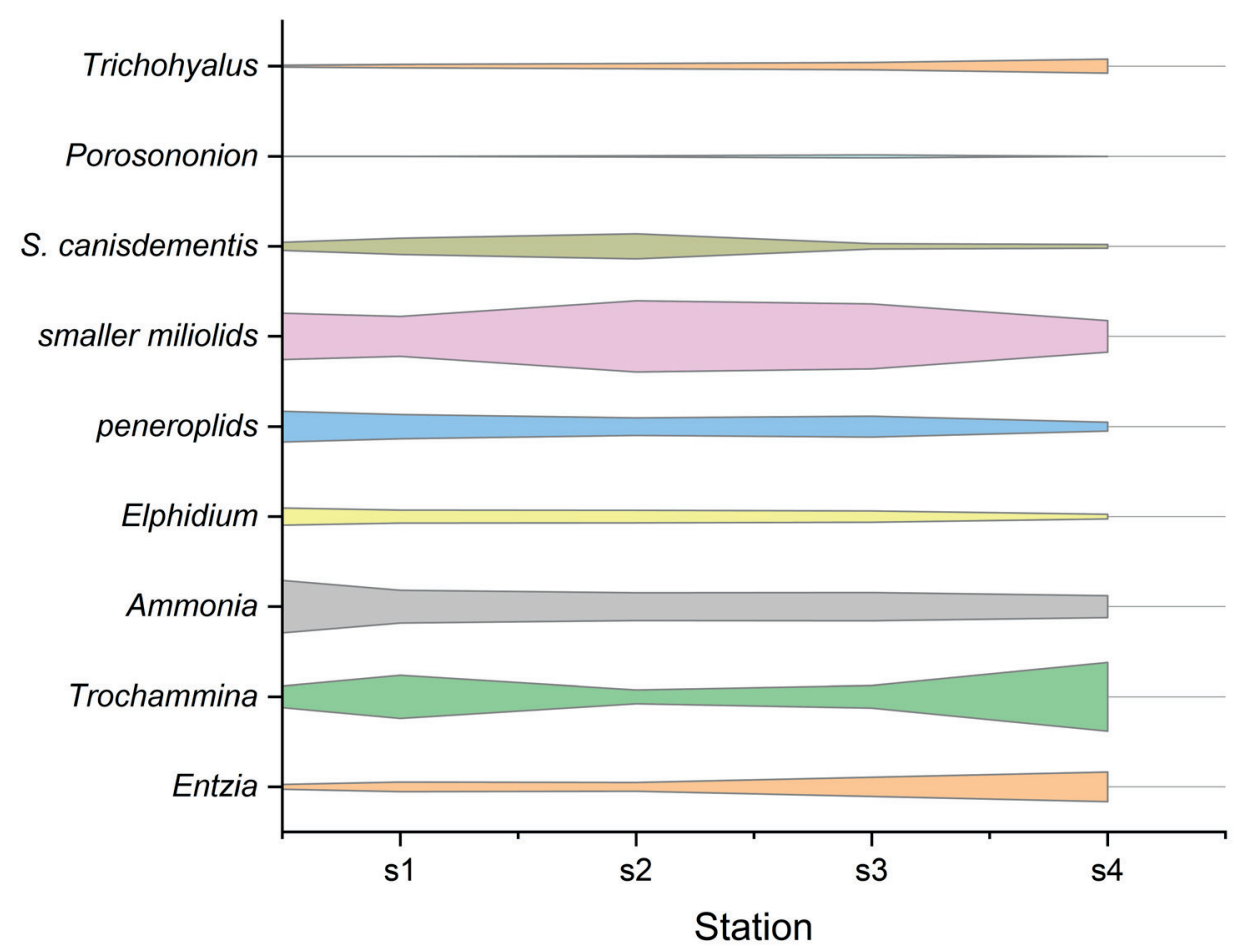

Fig. 3. Relative total abundance (Living+Dead) of the principle foraminiferal species in transect 1

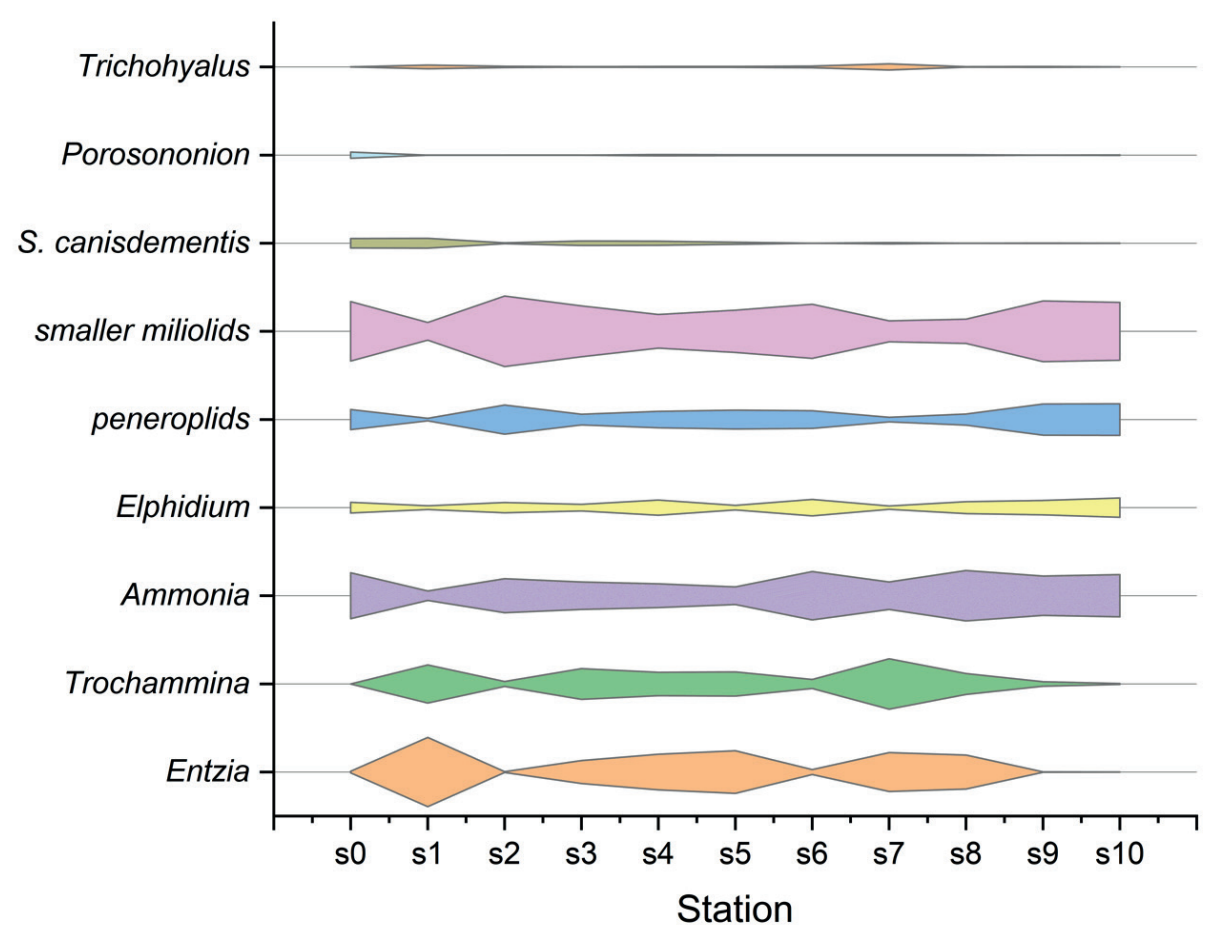

Fig. 4. Relative total abundance (Living+Dead) of the principle foraminiferal species in transect 2 


\section{DISCUSSION}

Temperate salt marshes in North America and northwest Europe are characterized by a benthic foraminiferal fauna dominated by agglutinated foraminifera, predominantly trochamminids (Scott \& Medioli 1980, Scott et al. 1990, Horton \& Edwards 2006). In the British marshes, the species Entzia macrescens occurs near HHW, whereas Trochammina inflata is dominant at in the middle marsh, and Miliammina fusca and various calcareous species characterize the lower marsh elevations and the mud flats (Horton \& Edwards 2006). Miliammina fusca is often also found in tidal channels. North American salt marshes contain more diverse trochamminids, including the genera Arenoparella, Balticammina, Siphotrochammina, and Tiphotrocha, as well as accompanying non-trochammind agglutinated foraminifera such as Reophax, Haplophragmoides and Polysaccammina (Edwards et al. 2004). In Bahrain, the diversity of agglutinated foraminifera is lower that of the North American salt marshes, consisting of only five genera. The composition of the marsh assemblage in Bahrain is more similar to that of the British marshes, with Entzia (= Jadammina in older publications) dominating at the fringe of the high marsh, Trochammina and Reophax extending to the middle marsh, and the agglutinated miliolid genus Agglutinella substituting for Miliammina in the low marsh and muddy tidal flat. Interestingly, the species Agglutinella kaminskii Garrison has the same fusiform shape and probably occupies a similar habitat as Miliammina fusca, but differs in its wall composition (see Garrison 2019). Additionally, Clavulina is found in association with Agglutinella in the low marsh, although at the time of our sampling only dead specimens of these genera were found. The largest adult specimens of Clavulina were observed at the lower edge of the marsh.

The species Entzia macrescens has a worldwide distribution and is likely dispersed by birds along their migration pathways (Holzmann \& Pawlowski 2017). The island of Bahrain sits squarely within the East Africa - West Asia flyway (Kube et al. 1998: fig. 24, Leblebicioglu et al. 2014: fig. 2). Much of the ornithological research shows migratory flyways via the Gulf and Bahrain heading north and eastward to central Asia and China (Sun et al. 2008, Si et al. 2009, de Fouw et al. 2017). However, there is evidence of flyways heading north and westward from Bahrain (Kube et al. 1998, Leblebicioglu et al. 2014). This bird migration flyway is from East Africa, Yemen, northward to Oman, Bahrain, Kuwait, Iraq, Turkey, Romania, and to other parts of Eastern Europe (Kube et al. 1998: fig. 24, Leblebicioglu et al. 2014: fig. 2). Entzia macrescens probably arrived with birds in Romanian salt ponds but to assume that it is the same cryptic species everywhere along migratory bird routes would necessitate a molecular investigation.

Tubli Bay is a well-known stopover point for migratory shore birds, and we have observed flamingos, egrets, and smaller shore birds at our sample locality. Trochammina inflata also has a worldwide distribution in salt marshes (Scott et al. 1990), although it has not been observed at the Entzia locality in landlocked Transylvania (Kaminski \& Filipescu 2011, Telespan et al. 2017). The species has been found in a mangrove-dominated environment in the U.A.E. (Fiorini et al. 2019), but our finding in Tubli Bay in Bahrain is the first report of the species in a salt-marsh environment in the western Arabian Gulf region. Based on the known migration pathway of the oystercatchers, Haematopus ostralegus iongipe, reported by Kube et al. (1998) and the great reed warbler, Acrocephalus arunddinaceus, reported by Leblebicioglu et al. (2014), we might expect to find trochamminids at other salt marshes in the western Gulf region, but this remains to be verified by an expanded survey. At our sampled locality larger specimens often display curious morphological deformities, such as irregular coiling or deformities of the chambers. A few specimens were found that display an abnormally lobate periphery, with radially elongated chambers (Plate 1, Figs. D1, D2). Deformities in peneroplids commonly observed in the Gulf region have been ascribed to extremes in temperature and salinity (Amao et al. 2018, Fiorini \& Lokier 2020), but it is not yet clear whether the occurrence of deformities in this population of $T$. inflata has an underlying environmental cause. 


\section{SYSTEMATICS}

In this section we use the classification of Kaminski (2014) for the agglutinated foraminifera, and Loeblich \& Tappan (1992) for the calcareous forms.

Class FORAMINIFERA d'Orbigny, 1826

Order LITUOLIDA Lankester, 1885

Suborder HORMOSININA Mikhalevich, 1980

Superfamily HORMOSINOIDEA Haeckel, 1894

Family REOPHACIDAE Cushman, 1927

Genus Reophax De Montfort, 1808

Type species Reophax scorpiurus de Montfort, 1808

\section{Reophax sp.}

Plate 1, Fig. A

Reophax sp. 1. Fiorini et al. 2019, pl. 1, fig. 3.

Remarks: Only a single specimen was recovered. Our specimen compares well with the species of Reophax illustrated by Fiorini et al. (2019) from the U.A.E. mangroves, but the final chamber in our specimen is somewhat more elongated.

Suborder TROCHAMMININA Saidova, 1981 Superfamily TROCHAMMINACEA Schwager, 1877 Family TROCHAMMINIDAE Schwager, 1877 Subfamily TROCHAMMININAE Schwager, 1877 Genus Trochammina Parker \& Jones, 1859 Type species Nautilus inflatus Montagu, 1808

Trochammina inflata (Montegu, 1808)

Plate 1, Figs. B-F

Nautilus inflatus Montegu, 1808, pl. 81, pl. 18, fig. 3. Trochammina inflata (Montegu). Parker \& Jones, 1859, p. 347; Scott \& Medioli, 1980, p. 44, pl. 3, figs. 12-14, pl. 4, figs. 1-3 (with synonyms); Brönnimann \& Whittaker, 1988, pl. 1, fig. 1 (neotype); Javaux \& Scott, 2003, p. 23, figs. 6.12-6.13; Fiorini et al., 2019, pl. 1, figs. 1-2; Semensatto, 2020, pl. 3, fig. 19.

Remarks: A neotype for Trochammina inflata (Montagu) was designated by Brönnimann \& Whittaker (1984) from Devon in SW England, and reillustrated by Brönnimann \& Whittaker (1988). It has been reported from mangals and salt marshes throughout the world (Javaux \& Scott 2003).
Our specimens from Bahrain can grow quite large, up to $725 \mu \mathrm{m}$ in diameter, and tend to acquire a lobate outline in the final chambers. Morphological deformities are commonly observed in the larger specimens, including irregular chambers or tighter, high trochospiral coiling. In Bahrain, it is observed in the high to middle part of the marsh. The species has also been found in a mangrove environment in the U.A.E. (Fiorini et al. 2019).

Subfamily JADAMMININAE Saidova, 1981

Genus Entzia Von Daday, 1883

Type species Trochammina inflata (Montagu) var. macrescens Brady, 1870

Entzia macrescens (Brady, 1870)

Plate 2, Figs. A-I

Trochammina inflata (Montegu) var. macrescens Brady, 1870, p. 290 , pl. 11, figs. $5 \mathrm{a}-\mathrm{c}$.

Entzia tetrostomella von Daday, 1883, p. 209, pl. 1, figs. 1-8.

Jadammina polystoma Bartenstein \& Brand, 1938, p. 381, figs. 1a-c, 2a-1; Pfleger et al., 1953, p. 9, pl. 2, figs. 35-37.

Trochammina macrescens Brady. Scott \& Medioli, 1980 , p. 44, figs. 1-8 (with synonyms).

Trochammina macrescens Brady (forma polystoma). Javaux \& Scott, 2003, p. 23, figs. 6.16-6.19.

Jadammina macrescens (Brady). Murray, 1979, p. 28 , fig. $6 \mathrm{k}, 1, \mathrm{~m}$.

Entzia macrescens (Brady). Filipescu \& Kaminski, 2011, p. 31, pl. 1, figs. 1-10, pl. 2, figs. 1-6 (with synonyms); Holzmann \& Pawlowski, 2017, pl. 1, figs. 1-4; Semensatto, 2020, pl. 2, fig. 4.

Description: Test-free, a flattened trochospire that tends to be nearly planispiral in the adult, chambers increasing gradually in size as added, sutures radial to slightly curved, periphery rounded. Wall imperforate, finely and sparsely agglutinated on a proteinaceous base. Aperture multiple; primary aperture a low interiomarginal equatorial slit, with one or more supplementary areal openings in the lower portion of the apertural face, each bordered by projecting lip.

Remarks: This species was first described by Brady (1870) from the River Dee in Wales, and thirteen years later, von Daday (1883) described an identical species under the name Entzia tetrostomella from a salt marsh near Deva, in Transylvania. 


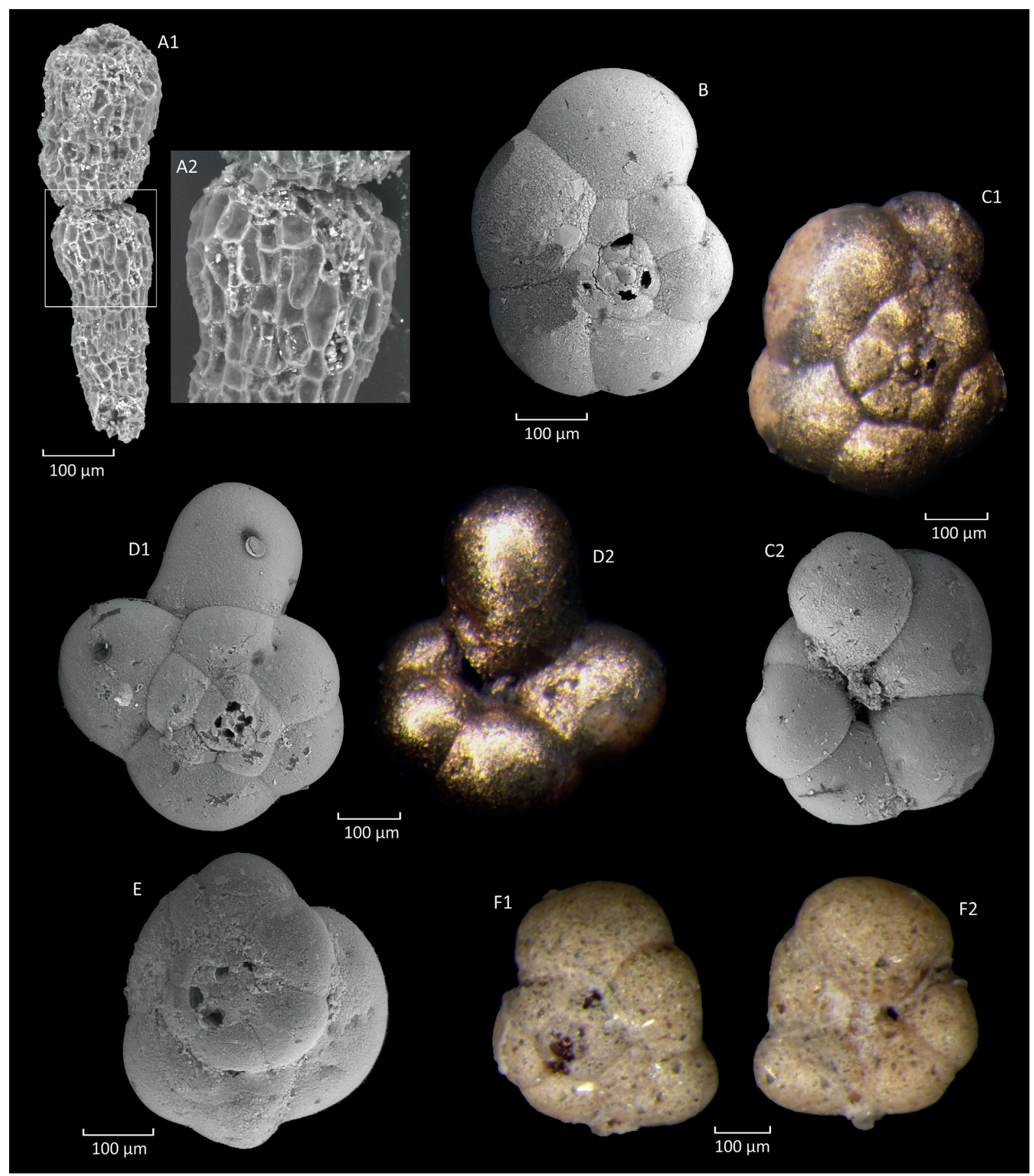

Plate 1. A: Reophax sp. (T2, sample 1); B: Trochammina inflata (Montegu) (T2, sample 1); C-E: Trochammina inflata (Montegu) with abnormalities (T1, sample 4); F: Trochammina inflata with abnormalities (sample VWO)

Filipescu \& Kaminski (2011) regarded the genus Entzia to be the senior synonym of Jadammina, while the species name macrescens (Trochammina macrescens Brady, 1870) has priority over the species name tetrastomella (Entzia tetrastomella Daday, 1883). Therefore, the correct combination for the species name is Entzia macrescens (Brady, 1870). Molecular studies by Holzmann \& Pawlowski (2017) have shown that specimens from Transylvania are almost identical with those collected from the Dovey Estuary in Wales, which is near Brady's type locality of Trochammina macrescens. 


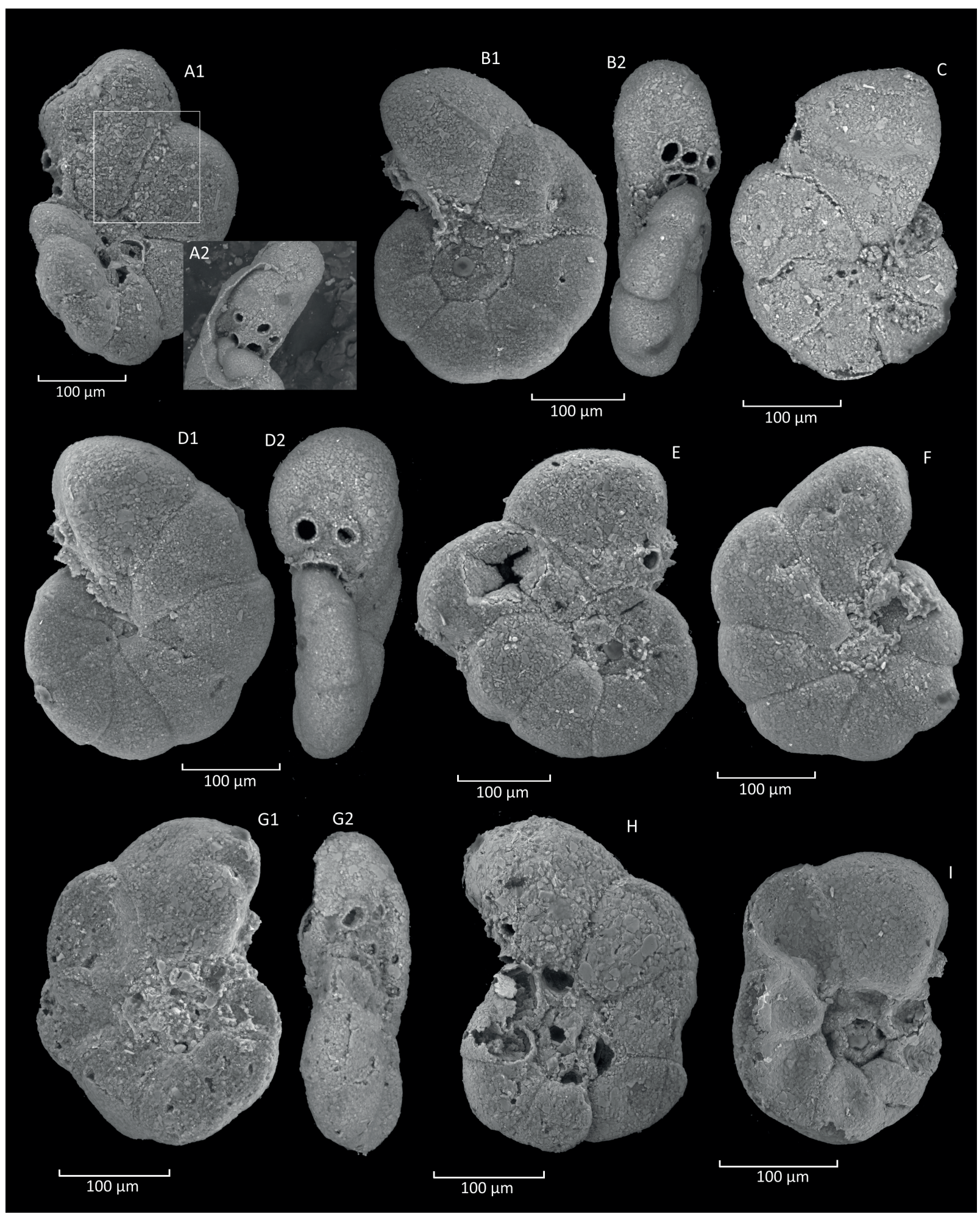

Plate 2. A-G: Entzia macrescens (Brady) (T2, sample 1); H, I: Entzia macrescens (Brady) (T1, sample 4)

The specimens from Bahrain display the typical features of the species, including the tendency for chambers to collapse upon drying. Smaller specimens may only possess a single supplementary aperture, and large specimens have as many as three supplementary apertures. Our specimens have a distinct tendency to acquire a lobate outline in the larger specimens, which may have as 
many as ten chambers in the final whorl. Some larger specimens exhibit morphological deformities (Plate 2, Figs. A, E, F). Previous authors have pointed out that $E$. macrescens may be very common, and this is certainly the case at our studied locality where it is the dominant species in the high marsh. Living specimens were observed in January and February, but not in samples collected during autumn. Telespan et al. (2017) observed that the Romanian population of the species reproduces in winter. To our knowledge this is the first report of Entzia macrescens from the Arabian Gulf region.

Order TEXTULARIIDA Delage \& Hérouard, 1896, emended Kaminski, 2004

Suborder TEXTULARIINA Delage \& Hérouard, 1896

Superfamily EGGERELLOIDEA Cushman, 1937

Family VALVULINIDAE Berthelin, 1880

Subfamily VALVULININAE Berthelin, 1880

Genus Clavulina d'Orbigny, 1826

Type species Clavulina parisiensis d'Orbigny, 1826

\section{Clavulina angularis d'Orbigny, 1826}

Plate 3, Figs. A-B

Clavulina angularis d'Orbigny, 1826, p. 268, pl. 12, fig. 2; Le Calvez, 1977, p. 10, figs. 1-3 (fig. 3 is the lectotype); Hottinger et al., 1993, p. 41, pl. 21, figs. 1-13.

Remarks: Only dead specimens were found. The largest specimens were found in the tidal channel at the low end of the marsh.

Order MILIOLIDA Lankester, 1885

Suborder MILIOLINA Lankester, 1885

Superfamily MILIOLACEA Ehrenberg, 1839

Family HAUERINIDAE Schwager, 1876

Subfamily SIGMOILINITINAE Luczkowska, 1974

Genus Sigmoilina Schlumberger, 1887

Type species Planispirina sigmoidea Brady, 1884

?Sigmiolina canisdementis Kaminski, Garrison and Waśkowska, sp. nov.

Plate 3, Figs. C-I

Derivation of name: from the fact that the type locality is frequented by a pack of feral dogs.
Type locality: Salt marsh next to the automotive dealership on the Shaikh Jaber Al-Subah Highway in Sitra, eastern side of Tubli Bay, Bahrain.

Holotype: Plate 3, Fig. C. Length $0.5 \mathrm{~mm}$, width $0.22 \mathrm{~mm}$; deposited in the EMRC, Kraków, catalog number: 7/27B.

Material: 111 specimens from 12 samples.

Type level: Recent.

Description: Text elongated elliptical in lateral view with parallel sides in the central portion, slightly compressed laterally. Length-width ratio 2.2-2.4. Four chambers are visible from the exterior on one side, only two chambers are visible on the opposite side. The long axis defined by the final two chambers is rotated about 30 degrees with respect to the axis defined by the chambers of the previous whorl. Wall thin and translucent, surface smooth. Aperture terminal, laterally compressed, provided with an elongated bar- or spoon-like tooth whose basal and distal ends are broadened. The tooth nearly fills the aperture.

Remarks: In its apertural features, this species resembles the Red Sea species "Quinqueloculina" eburnea (d'Orbigny, 1839) as depicted by Hottinger (1993, p. 59, pl. 53, figs. 9-11, pl. 54, figs. 1-5). However, our specimens differ in being slenderer and more elongated than either d'Orbigny's specimens figured by Le Calvez (1977) or Hottinger's specimens. Hottinger (1993) described the chamber arrangement as quadriloculine, and therefore only tentatively assigned the species to Quinqueloculina. In the current study $S$. canisdementis sp. nov. is the only miliolid consistently occurring as a live population in the higher reaches of the salt marsh. At the time of sampling it was the most abundant living foraminiferal species on the marsh.

Family PENEROPLIDAE Schultze, 1854

Genus Peneroplis de Montfort, 1808

Type species Nautilusplanatus Fichtel \& Moll, 1798

Peneroplis planatus (Fichtel \& Moll, 1798)

Plate 3, Figs. J-K

Nautilus planatus var. a, b, g Fichtel \& Moll, 1798, p. 91, pl. 16, figs. a-i.

Peneroplis planatus (Fichtel \& Moll); Cimerman \& Langer, 1991, p. 50, pl. 50, figs. 1-6; Förderer \& Langer, 2018, p. 66, pl. 30, figs 16-18; Amao et al., 2018, fig. 5, 5-8; Fiorini \& Loker, 2020, pl. 1, fig. 1. 


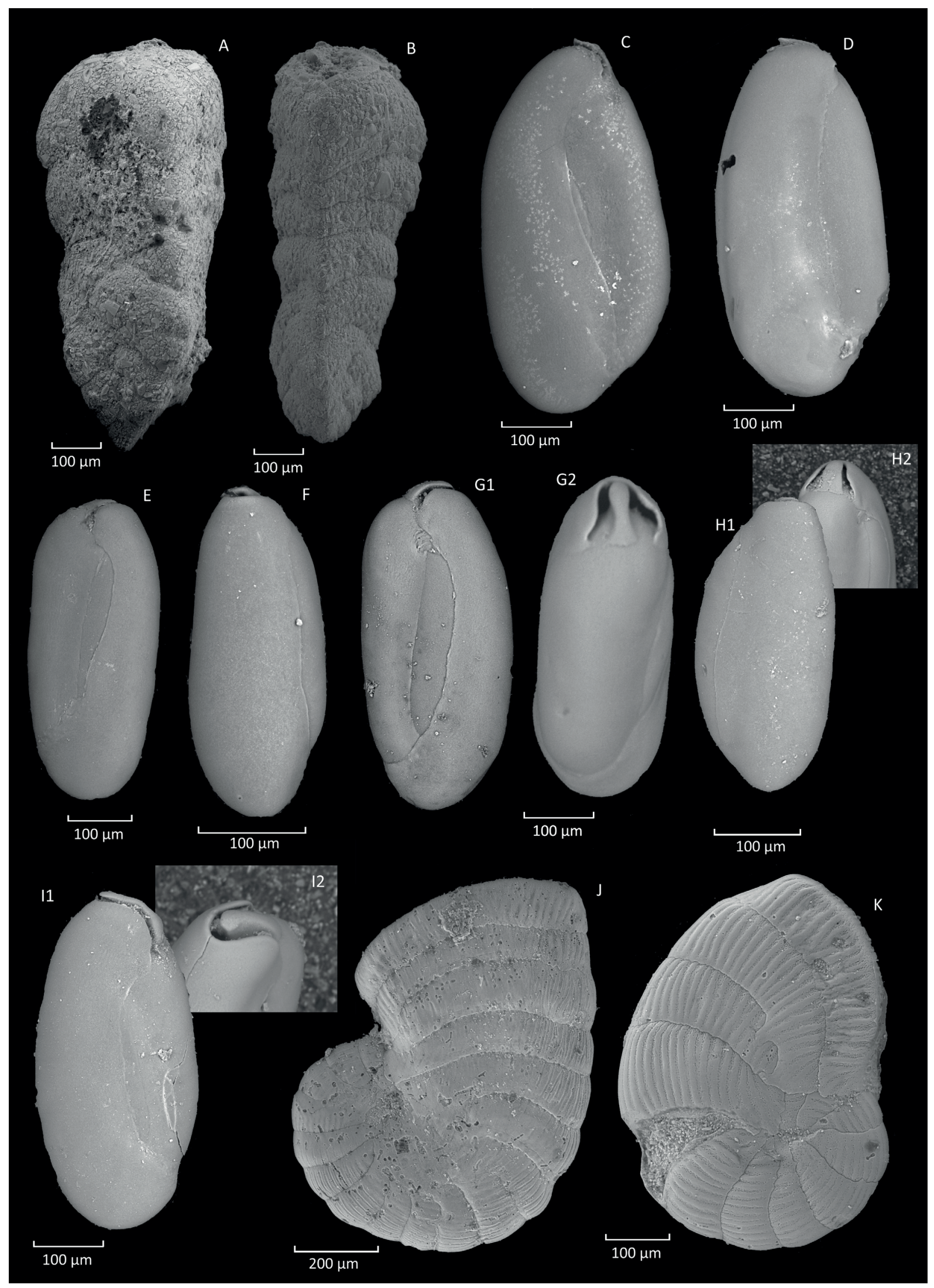

Plate 3. A: Clavulina angularis d'Orbigny (T1, sample 3); B: Clavulina angularis d'Orbigny (T2, sample 2); C: Sigmoilina canisdementis Kaminski, Garrison and Waśkowska, sp. nov., holotype; D-I: Sigmoilina canisdementis Kaminski, Garrison and Waśkowska, sp. nov., paratypes (samples VW0, VW1, VW2); J, K: Peneroplis planatus (Fichtel \& Moll) (sample VW5) 
Remarks: For the taxonomy of the peneroplids we follow Förderer \& Langer (2018). Specimens from the landward side of the salt marsh are mostly juveniles, whereas adult specimens are found at the seaward end of the transect. For the purpose of this study we did not differentiate Peneroplis planatus from Peneroplis pertusus (Forskål), as juvenile specimens are difficult to separate. Some larger specimens display deformities, as noted by Amao et al. (2018) from the hypersaline Salwa Bay in Saudi Arabia and by Fiorini \& Lokier (2020) in a population from a lagoon in the U.A.E. Whether or not deformities in Peneroplis are caused by variations in temperature and/or salinity remains to be verified experimentally.

Order ROTALIIDA Lankester, 1885

Suborder ROTALIINA Lankester, 1885

Superfamily CHILOSTOMELLACEA Brady, 1881

Family TRICHOHYALIDAE Saidova, 1981

Genus Trichohyalus Loeblich \& Tappan, 1953

Type species Discorbis bartletti Cushman, 1933

Trichohyalus aguayoi (Bermúdez, 1935)

Plate 4, Figs. A-C

Discorbis aguayoi Bermúdez, 1935, p. 204, pl. 15, figs. 10-14.

Discorinopsis vadescens Cushman \& Brönnimann, 1948, p. 20, pl. 4, figs. 9, 10.

Discorinopsis aguayoi (Bermúdez). Pfleger et al., 1953, p. 7, pl. 4, figs. 23-24; Arnold, 1954, p. 7, pl. 2, figs. 1-17; Javaux \& Scott, 2003, p. 14, figs. 6.1-6.2; Semensatto, 2020, pl. 2, fig. 3.

Trichohyalus aguayoi (Bermúdez). Bermúdez \& Seiglie, 1963, p. 176, pl. 26, fig. 4; Avnaim-Katav et al., 2017, pl. 2, fig. 4 .

Remarks: This species had often been reported as "Discorinopsis" aguayoi, even though it clearly has a hyaline calcareous test, and Bermúdez (1935) had originally placed it in the calcareous (rotaliid) genus Discorbis. The genus Discorinopsis is an agglutinated taxon from the Eocene of Florida (Cole 1941). We have recovered several live specimens from our sampled locality. Bermúdez \& Seiglie (1963) reported it as abundant in mangrove lagoons in Trinidad and in the Gulf of Cariaco, Venezuela. It is found in marine mangrove ponds in Bermuda (Javaux \& Scott 2003) and Brazil (Semensatto 2020). Avnaim-Katav et al. (2017) reported it from a salt marsh in the Tijuana River estuary in southern California.

Family ROTALIIDAE Ehrenberg, 1839

Subfamily AMMONIINAE Saidova, 1981

Genus Ammonia Brünnich, 1772

Type species Nautilus beccarii Linné, 1758

Ammonia tepida (Cushman, 1926)

Plate 4, Figs. D-G

Rotalia beccarii (Linnaeus) var. tepida Cushman, 1926, p. 79, pl. 1.

Ammonia cf. A. tepida (Cushman, 1926) Type 1. Förderer \& Langer, 2018, p. 132, pl. 49, figs. 1-3.

Remarks: Juvenile specimens were living on the salt marsh at the time the samples were collected. Our specimens are plano-convex and are more like the "type 1" variety of Förderer \& Langer (2018). Holzmann (2000) and Hayward et al. (2004), have shown that the genus Ammonia contains different phylotypes that may constitute distinct species. Small morphotypes of Ammonia with no distinct ornamentation are called Ammonia tepida by many authors, but according to molecular results they belong to different species (M. Holzmann 2020, personal communication).

Subfamily ELPHIDIINAE Galloway, 1933

Genus Elphidium de Montfort, 1808

Type species Nautilus macellus var. b Fichtel \& Moll, 1798

\section{Elphidium spp.}

Plate 4, Figs. H-K

Remarks: We did not differentiate the species of Elphidium in this study. The specimens are mostly the keeled Elphidium advenum, and a second species with a broadly rounded periphery.

Genus Porosononion Putrya in Voloshinova, 1958 Type species Nonionina subgranosa Egger, 1857

\section{Porosononion sp.}

Remarks: This taxon is rare in the studied material. Our specimens resemble the Indian Ocean specimens of Porosononion simplex (Cushman) as illustrated by Parker (2009: figs. 499, 500). 


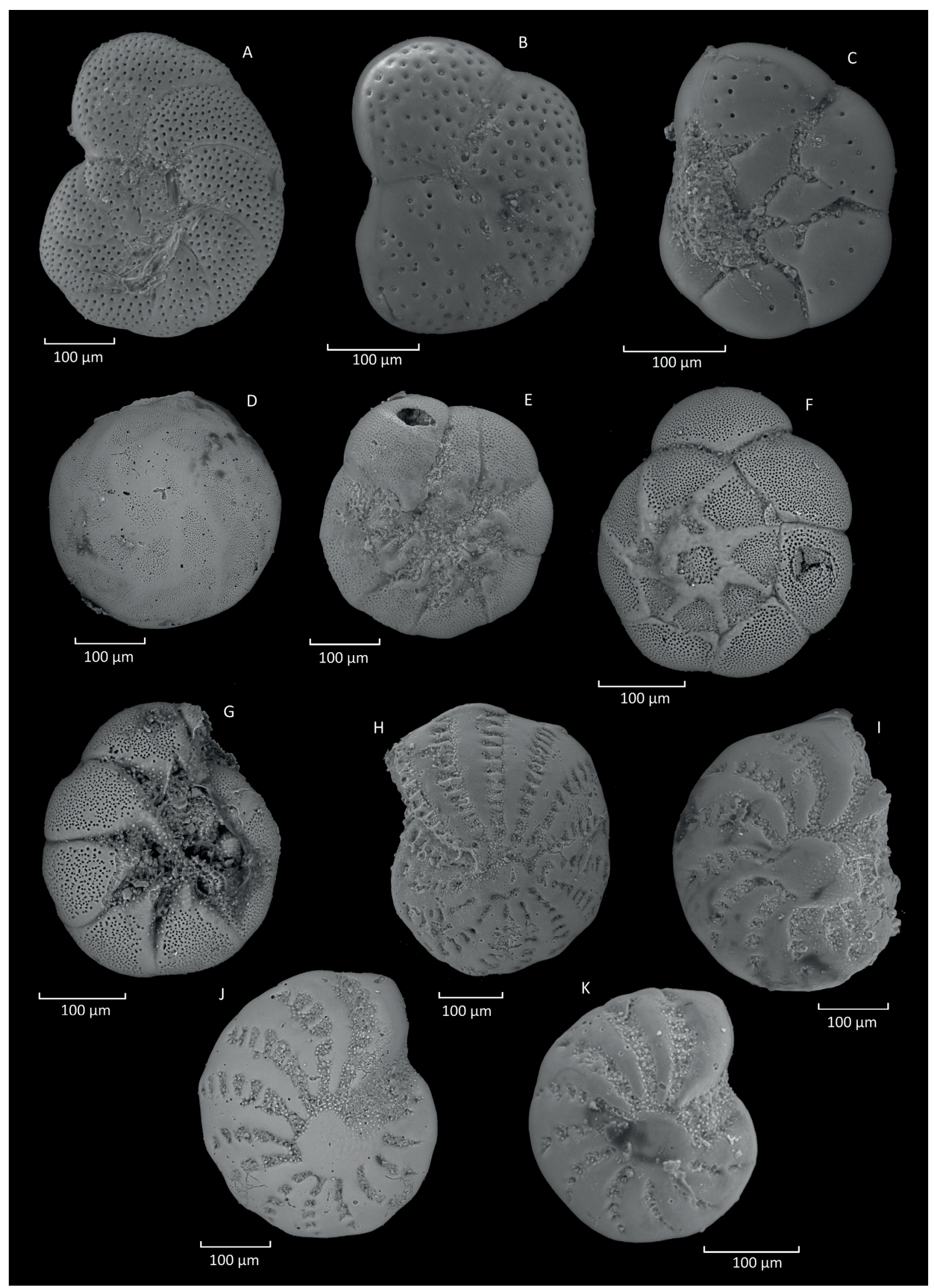

Plate 4. A, B: Trichohyalus aguayoi (Bermúdez) (sample VW1); C: Trichohyalus aguayoi (Bermúdez) (T2, sample 4); D-G: Ammonia tepida (Cushman) (sample VW4); H-K: Elphidium sp. (sample VW5) 


\section{CONCLUSIONS}

We report the first discovery of a trochamminid-dominated foraminiferal assemblage from a salt marsh in Bahrain, in the western Arabian Gulf. The assemblage is taxonomically less diverse than trochamminid-dominated assemblages known from temperate salt marshes or the Caribbean and is comprised exclusively of Entzia macrescens and Trochammina inflata. Accessory species include the agglutinated species Reophax sp., Clavulina angularis, and Agglutinella kaminskii, as well as the calcareous benthic genera Ammonia, Elphidium, Trichohyalus, and diverse larger and smaller miliolids. An elevation-related zonation is observed in the assemblage composition, with Entzia dominating at the higher landward limit of the marsh, and rotaliids and miliolids dominating at the lower limit of the marsh, near the tidal channel. Only dead foraminifera were found during autumn 2019, while living specimens were recovered in January and February 2020.

This research was sponsored by a grant from the Deanship of Scientific Research, KFUPM (Grant IN161002). We thank Adam Fheed (AGH) for help with sample collection; AGH subvention funds for photographic documentation; and Brent Wilson and two anonymous reviewers for reading a draft of the manuscript.

\section{REFERENCES}

Amao A.O., Kaminski M.A. \& Setoyama E., 2016. Diversity of Foraminifera in a shallow restricted lagoon in Bahrain. Micropaleontology, 62, 3, 197-211.

Amao A.O., Kaminski M.A. \& Babalola L., 2018. Benthic foraminifera in hypersaline Salwa Bay (Saudi Arabia): An insight into future climate change in the Gulf Region? Journal of Foraminiferal Research, 48, 29-40.

Arnold Z., 1954. Discorinopsis aguayi (Bermúdez) and Discorinopsis vadescens Cushman and Brönnimann: A study of variation in cultures of living foraminifera. Contributions from the Cushman Foundation for Foraminiferal Research, 5, 1, 4-13.

Avnaim-Katav S., Gehrels W.R., Brown L.N., Fard E. \& MacDonald G.M., 2017. Distributions of salt-marsh foraminifrea along the coast of SW California, USA: Implications for sea-level reconstructions. Marine Micropaleontology, 131, 25-43.

Bartenstein H. \& Brand E., 1938. Die Foraminiferen-Fauna des Jade-Gebietes. Senckenbergiana, 20, 5, 381-412.
Basson P.W. \& Murray J.W., 1995. Temporal variations in four species of intertidal foraminifera, Bahrain, Arabian Gulf. Micropaleontology, 41, 1, 69-76.

Bermúdez P.J., 1935. Foraminíferos de la Costa Norte de Cuba. Memorias de la Sociedad Cubana de Historia Natural, 9, 129-224+ 8 pls.

Bermúdez P.J. \& Seiglie G.A., 1963. Estudio sistematico de los Foraminíferos del Golfo de Cariaco. Boletin del Instituto Oceanográfico de la Universidad de Oriente, 2, 2, 3-267.

Brady G.S \& Robertson D., 1870. The ostracoda and foraminifera of tidal rivers. With an analysis and descriptions of the foraminifera, by H.B. Brady. The Annals and Magazine of Natural History, 6, 1-33.

Brönnimann P. \& Whittaker J.E., 1984. A neotype for Trochammina inflata (Montagu) (Protozoa: Foraminiferida). Bulletin of the British Museum of Natural History (Zoology), 46, 4, 311-315.

Brönnimann P. \& Whittaker J.E., 1988. The trochamminaceous test and the taxonomic criteria used in the classification of the superfamily Trochamminacea. Abhandlungen des geologischen Bundesanstalt, 41, 23-39.

Cimerman F. \& Langer M.R., 1991. Mediterranean Foraminifera. Dela (Slovenska akademija znanosti in umetnosti. Razred za naravoslovne vede), 30, Slovenska akademija znanosti in umetnosti, Ljubljana.

Cole W.S., 1941. Stratigraphy and paleontology studies of wells in Florida. Florida State Geological Survey, Geological Bulletin, 19, i-vi, 1-91.

von Daday E., 1883. On a polythalamian from the salt-pools near Déva in Transylvania. The Annals and Magazine of Natural History, 83, 349-363.

Edwards R.J., Wright A.J. \& van de Plassche O., 2004. Surface distributions of salt-marsh foraminifera from Connecticut, USA: modern analogues for high-resolution sea level studies. Marine Micropaleontology, 51, 1-2, 1-21.

Filipescu S. \& Kaminski M.A., 2011. Re-discovering Ent$z i a$, an agglutinated foraminifer from the Transylvanian salt marshes. [in:] Kaminski M.A. \& Filipescu S. (eds.), IWAF-8: proceedings of the eighth international workshop on Agglutinated foraminifera: Cluj-Napoca, Romania, September 7-13, 2008, Grzybowski Foundation Special Publication, 16, Presa Universitară Clujeană, Cluj-Napoca, 29-35.

Fiorini F. \& Lokier S.W., 2020. Abnormal test growth in larger benthic foraminiferal from hypersaline coastal ponds of the United Arab Emirates. Micropaleontology, 66, 2, 151-156.

Fiorini F., Lokier S.K., Garrison T. \& Kaminski M.A., 2019. Agglutinated foraminifera from Recent mangrove environments of the United Arab Emirates (UAE). Micropaleontology, 65, 3, 301-304.

Förderer M. \& Langer M.R., 2018. Atlas of benthic foraminifera from coral reefs of the Raja Ampat Archipelago (Irian Jaya, Indonesia). Micropaleontology, 64, 1-2, $1-170$.

de Fouw J., Thorpe A., Bom R.A., de Bie S., Camphuysen C.J., Etheridge B., Hagermeijer W., Hofstee L., Jager T., Kelder L., Kleefstra R., Kersten M., Nagy S. \& Kleefstra R.H.G., 2017. Barr Al Hikman, a major shorebird hotspot within the Asian-East African flyway: results of three winter surveys. Wader Study, 124, 10-25. 
Garrison T.F., 2019. The microscopic mineral collector of the sea: Agglutinella kaminskii n. sp., a new benthic foraminifer from the Arabian Gulf. Micropaleontology, 65, 4, 277-283.

Hayward B.W., Holzmann M., Grenfell H.R., Pawlowski J. \& Triggs C.M., 2004. Morphological distinction of molecular types in Ammonia - towards a taxonomic revision of the world's most commonly misidentified foraminifera. Marine Micropaleontology, 50, 237-271.

Holzmann M., 2000. Species concept in foraminifera: Ammonia as a case study. Micropaleontology, 46 Supplement $1,21-37$.

Holzmann M. \& Pawlowski J., 2017. A note on the phylogenetic position of Entzia macrescens (Brady). [in:] Kaminski M.A. \& Alegret L. (eds.), Proceedings of the ninth international workshop on Agglutinated foraminifera: Zaragoza, Spain, September 3-7, 2012, Grzybowski Foundation Special Publication, 22, The Grzybowski Foundation \& Micropress Europe, Kraków, 75-79.

Hottinger L., Halicz E. \& Reiss Z., 1993. Recent foraminifera from the Gulf of Aqaba, Red Sea. Dela (Slovenska akademija znanosti in umetnosti. Razred za naravoslovne vede), 33, Slovenska akademija znanosti in umetnosti, Ljubljana.

Horton B.P. \& Edwards R.J., 2006. Quantifying Holocene sea-level change using intertidal foraminifera: Lessons from the British Isles. Cushman Foundation for Foraminiferal Research Special Paper, 40, 3-97.

Javeau E.J. \& Scott D.B., 2003. Illustration of modern benthic foraminifera from Bermuda and remarks on distribution in other subtropical/tropical areas. Palaeontologia Electronica, 6, 4, 1-29.

Kaminski M.A., 2014. The year 2010 classification of the agglutinated foraminifera. Micropaleontology, 61, 1, 89-108.

Kube J., Korzyukov A.I., Nankinov D.N., Münster O.A.G. \& Weber P., 1998. The northern and western Black Sea region - the Wadden Sea of the Mediterranean Flyway for wader populations. International Wader Studies, 10, 379-393.

Kumar R.A., Naidu K.B. \& Kaladhar R., 2014. Agglutinated foraminifera from the Chilka Lake, Orissa, east coast of India. Indian Journal of Geo-Marine Sciences, 44, 4, 531-538.

Leblebicioglu H., Eroglu C., Erciyas-Yavuz K., Hokelek M., Acici M. \& Yilmaz H., 2014. Role of migratory birds in spreading Crimean-Congo Hemorrhagic Fever, Turkey. Emerging Infectious Diseases, 20, 8, 1331-1334.

Le Calvez Y., 1977. Révision des Foraminifères de la collection d'Orbigny: II. Foraminifères de l'île de Cuba. Tome 2. Cahiers de Micropaléontologie, 11, Muséum national d'Histoire naturelle, Paris.

Loeblich A.R. \& Tappan H., 1992. Present status of foraminiferal classification. [in:] Takayanagi Y. \& Saito T. (eds.), Studies in Benthic Foraminifera, Proceedings of the Fourth International Symposium on Benthic Foraminifera, Sendai, 1990, Tokai University Press, 93-102.

Montagu G., 1808. Testacea Britannica; supplement. S. Woolmer, Exeter, England.

Murray J.W., 1979. British Nearshore Foraminiferids. [in:] Kermack D.K. \& Barnes R.S.K. (eds.), Synopses of the British Fauna, 16, Academic Press, London, 1-68.
Parker J.H., 2009. Taxonomy of Foraminifera from Ningaloo Reef, Western Australia. AAP Memoir, 36, Association of Australasian Palaeontologists.

Parker W.K. \& Jones T.R., 1859. On the nomenclature of the foraminifera. II. On the species enumerated by Walker and Montagu. Annals and Magazine of Natural History, 3, 4, 333-351.

Phleger F.B., 1970. Foraminiferal populations and marine marsh processes. Limnology and Oceanography, 15, 4, 522-534.

Phleger F.B., Parker F.L. \& Peirson J.F., 1953. Ecology of Foraminifera from San Antonio Bay and environs, southwest Texas. Cushman Foundation for Foraminiferal Research Special Publication, 2, Cushman Foundation for Foraminiferal Research.

Saunders J.B., 1957. Trochamminidae and certain Lituolidae (Foraminifera) from the Recent brackish-water sediment of Trinidad, British West Indies. Smithsonian Miscellaneous Collections, 134, Smithsonian Institution.

Shmal'gauzen O.I., 1950. Novyy vid foraminifery iz ozera Balpash-sor (Kazakhstan) [Шмальгаузен О.И., 1950. Новый вид фораминиферы из озера Балпаш-сор (Казахстан)]. Doklady Akademii Nauk SSSR [Доклады Академии наук СССР], 75, 6, 869-872.

Scott D.B. \& Medioli F.S., 1978. Vertical zonations of marsh foraminifera as accurate indicators of former sea levels. Nature, 272, 5653, 528-531.

Scott D.B. \& Medioli F.S., 1980. Quantitative studies of marsh foraminiferal distributions in Nova Scotia: Implications for sea level studies. Cushman Foundation for Foraminiferal Research Special Publication, 17, Cushman Foundation for Foraminiferal Research.

Scott D.B., Schnack E.J., Ferrero L., Espinosa M. \& Barbarosa C.F., 1990. Recent marsh foraminifera from the east coast of south America: comparison to the Northern hemisphere. [in:] Hemleben C., Kaminski M.A., Kuhnt W. \& Scott D.B. (eds.), Paleoecology, Biostratigraphy, Paleoceanography and Taxonomy of Agglutinated Foraminifera, NATO ASI Series C, 327, Springer, 717-737. Seedo K.A., Abido M.S., Salih A.A. \& Abahussain A., 2017. Assessing Heavy Metals Accumulation in the leaves and sediments of Urban Mangroves (Avicennia mari$n a$ (Forsk.) Vierh.) in Bahrain. International Journal of Ecology, 2017, 3978216, 1-8.

Semensatto D., 2020. A key to the identification of agglutinant and monothalamous foraminiferal from Brazilian mangroves. Ocean and Coastal Research, 68, e20297, 1-24.

Si Y., Skidmore A.K., Wang T., De Boer W.F., Debba P., Toxopeus A.G., Li L. \& Prins H.H.T., 2009. Spatio-temporal dynamics of global H5N1 outbreaks match bird migration patterns. Geospatial Health, 4, 1, 65-78.

Sun G. \& Yang H., 2008. A study on the space-time dynamic of global avian influenza and relationship with bird migration. International Journal of Business and Management, 3, 2, 10-17.

Telespan A., Balc R. \& Kaminski M.A., 2017. Seasonal variation in populations of Entzia macrescens (Brady) from a salt marsh in Transylvania, Romania. [in:] Kaminski M.A. \& Alegret L. (eds.), Proceedings of the ninth international workshop on Agglutinated foraminifera: Zarago$z a$, Spain, September 3-7, 2012, Grzybowski Foundation Special Publication, 22, The Grzybowski Foundation \& Micropress Europe, Kraków, 215-221. 